\title{
N.P. Troubetskoy - an Outstanding Leader of the Moscow Branch of the Russian Musical Society
}

\author{
Olga Glushkova \\ State Institute of art studies \\ Moscow, Russia \\ E-mail: olga_rein@mail.ru
}

\begin{abstract}
The article is devoted to one of the leaders of the Moscow branch of the Imperial Russian musical society, Prince Nikolai P.Troubetskoy, who participated, along with many outstanding representatives of Russian musical culture, the August patrons of the Society and well-known philanthropists in the creation of concert and educational traditions of musical life of Moscow and the Moscow Conservatory.
\end{abstract}

Keywords-Prince N.P. Troubetskoy; Russian Musical Society; Moscow conservatory; Ahturka

\section{INTRODUCTION}

The 19th century saw dramatic changes in the history of Russian musical culture. Undoubtedly, the establishment of the Russian Musical Society in 1859 (that also existed under the name of the Imperial Russian Musical Society from 1873 till 1917), which played the most essential part in the becoming of the national composition and performing schools as well as traditions in musical education.

The idea to create the RMS emerged in the course of discussions at the imperial court, among the confidants of the Grand Princess Elena Pavlovna (1806-1873), the wife of the Grand Prince Michael Pavlovich (who was the son of Paul I), whose number also included Count M.Yu. Vielgorsky and the resplendent pianist A.G. Rubinstein. According to their plot, the Society was to implement an educational project in order to improve musical education on a nationwide scale i.e. to found domestic musical educational institutions and to organize concerts. The RMS pronounced its main aim “... development of musical education and musical taste in Russia, encouragement of domestic talents" ${ }^{1}$ (an excerpt taken from the first Statute of the Society).

The era of the IRMS marked the prime of the Russian musical art, elucidated by the ingenious composers and performers who made eternal and priceless contributions to the world musical culture. These are P.I. Tchaikovsky, the Rubinstein brothers, S.I. Taneyev, N.A. Rimsky-Korsakov, V.I. Safonov, A.I. Siloti, A.N. Scriabin, S.V. Rachmaninov, and yet many more others who brought glory to Russia.

${ }^{1}$ RSHA. F.1286. S. 27. D.267.
The Society existed during the reigns of Emperors Alexander II, Alexander III, and Nicholas II. Ever since its foundation, the RMS has always been under the auspices of Grand Princes and Duchesses: Elena Pavlovna, Nikolai Konstantinovich, Alexandra Iosifovna, Konstantin Konstantinovich, Sergei Aleksandrovich, and Princess Elena of Sachsen-Altenburg.

The main figures of the IRMS were the princes V.F. Odoyevsky, N.P. Troubetskoy, D.A. Obolensky and A.A. Obolensky, who were philanthropists; the Rubinstein brothers, the pianists; the composers A.S. Dargomyzhsky and P.I. Tchaikovsky. Many town governors, important industrialists, merchants, and landlords contributed to the very existence and elaboration of the Society's endeavours: M.P. Aznachevsky, S.M. Tretyakov, N.A. Alexeyeva and K.S. Alexeyev, K.V. Rukavishnikov, G.G. Solodovnikov. There were ordinary donators from bourgeoisie among the honoured members of the Society - and the famous foreign composers: F. Liszt, H. Berlioz, R. Wagner.

The IRMS was credited for creating the domestic system of professional musical education as well as disseminating musical knowledge, which was implemented in its educational institutions: Musical Classes, Academies, and Conservatoires (before 1917, the Conservatoires in SaintPetersburg, Moscow, Saratov, Odessa, and Tiflis [modern Tbilisi] were founded).

The Society opened its offices in dozens of provincial towns (Kiev, Voronezh, Nizhny Novgorod, Omsk, Tambov, Tomsk, Odessa, Kharkov, Yekaterinoslavl' (nowadays Dnepropetrovsk), Yekaterinodar (nowadays Krasnodar), Poltava, Astrakhan', Simferopol', Yalta, Yaroslavl', Irkutsk, Vladivostok etc.) and learning centres nearby, which fulfilled the Society's tasks in disseminating musical education among the citizens (regular organization of concerts with symphonic and chamber works, invitation of foreign performers, artistic promotion and funding for domestic composers and performers).

As the first Russian educational institutions specializing in instructing performers, composers, music teachers opened, the new occupation of a musician emerged in the country. Representatives of the new profession possessed social benefits: they could have civil ranks, receive state awards and pension, move up the career ladder, enjoy immunity 
from compulsory military service etc. Apart from that, the RMS created essential musical instruction whereby students acquired skills from beginner to proficiency levels and learned general compulsory subjects serving to broaden their horizons and to teach them to think in a historic and a scientific manner.

Not only did the Society allow young generations to get excellent musical education in the homeland but it also ensured that they approved themselves in all of their specializations: as performers, composers, teachers, public persons. As a result, thanks to the full-scale work of the Society, a constellation of eminent personalities was raised, of patriots who deeply cared about their motherland's destiny and its cultural prosperity. As years went by, more and more graduates of the first Russian conservatoires in Saint Petersburg and Moscow applied their talents in concert halls, opera theatres, and musical institutions all over the country.

By the beginning of the $20^{\text {th }}$ century, the Society's work was crowned by the grand success: Russian musical art was celebrated worldwide.

\section{THE Prince N.P.TROUBETSKOY AS OUTSTANDING LEADER OF THE MOSCOW BRANCH OF THE RUSSIAN MUSICAL SOCIETY}

Among the main activists of the Moscow RMS, there were the key representatives of the $19^{\text {th }}$-century Russian culture: the princes V.F. Odoyevsky and N.P. Troubetskoy, the first director of the Moscow conservatoire and eminent pianist N.G. Rubinstein and the great composer P.I. Tchaikovsky. Yet only the personality of N.P. Troubetskoy sank into oblivion. But he, the state and public personality who took part in military campaigns (the Hungarian and Crimean campaigns in 1849-1854), received many awards, held office in the course of a lifetime (e.g. he was the vice-governor of Kaluga from 1876 till 1885), did a lot for the sake of prosperity of musical culture as well. He was a member of the Moscow RMS Office starting from the 1860s, organization of the Conservatoire's work and the Society's concerts is due to him, so he definitely deserves a full and good memory.

The prince N.P. Troubetskoy (1828-1900) was one of key figures during the most difficult period of the Moscow RMS's existence - at the stage of its organization. The theses fundamental for the work of the RMS in Moscow were brought to life mainly thanks to personal and professional qualities and extraordinary organizational aptitudes of the prince. For instance, the fact that the Moscow Office headed by the prince Troubetskoy had to appeal to the highest Patroness of the Society at the time when the fate of the Moscow Office was being determined is a vivid example of the kind of problems the RMS had to solve in the very beginning of the strenuous path to the evolved musical life in Moscow.

This document - a letter to the Grand Princess Elena Pavlovna from the Moscow representatives of the Society, primarily signed by Troubetskoy,- - bears the date of the $26^{\text {th }}$ of January, 1865 and starts with the short statement of the birth history of the Moscow organization, its activities, and the petition for opening the Musical Academy.

"Your Imperial Highness!

Your Most Gracious Majesty!"

In 1860 , the RMS administration started its activities in Moscow.

In the Society's Statute, which aimed at the general goal "The development of musical education and taste for music in Russia", we anticipated the ubiquitous action of the Society in Russia, therefore there is no mention as for whether there will be the Administration, consisting of the 5 Directors, in one exact city, or else there will be administrations whenever we operate. On these grounds and by authorization of the already-existing Saint Petersburg Administration, yet without any funding on her part, the Moscow RMS opened, whose activities resulted in following - the number of its members is rising and currently amounts to 1000 persons. In 1862, His Imperial Highness blessed us by His presence at the Society's meeting, and in the last, 1864 year, Your Imperial Highness did. The funds of the Society in Moscow have increased annually due to membership fees, public concerts, and, besides these, from members' donations aiming at developing the Society's activities in Moscow - with this aim Your Imperial Highness deigned to donate 1000 silver rubles last year, specifically on the organization of the Musical Academy in Moscow. As the funds were increasing, the Moscow Administration's range of activities was expanding, so that currently, the Society has opened musical classes for playing almost all instruments and for singing, where there are 150 students who learn, making payments from 2 up to 8 rubles a month, and 200 students who learn free of charge. The free class of choir singing combined with music theory according to the Chevet's method which we introduced here was such a success that the military department saw how in fact simpler and easier musical education became and started communicating with us in order to teach this method in military academies. Thus we hope, as time goes by, to attain our goal-to disseminate musical education and taste for music in all strata of society" 2 .

In this written appeal to the Grand Princess we uncover the great concern of the Moscow RMS members about their discriminated status along the lines of their Society Statute. "Here is the cause which incited us to ask Your Imperial Highness last year about a supplement of our statute, in terms of giving us full independence of our actions as well as funds, which is not defined in the statute precisely enough. Nowadays, we have received for our consideration a project of the new statute which will not only lay constraints on all our actions, but also not guarantee the integrity of our funds, since in this project's sense our actions and funds will be definitely paralyzed by the power of the Main Directorate; for instance, the appointment of the directors in place of the quitting ones is left to the Main Directorate; on what grounds can the Main Directorate appoint or not appoint the people

2 The Glinka National Museum Consortium of Musical Culture. F.80. S.I.3569. 
whose advantages can be known only to the local administration - which chose them? The appointment of the supervisor by the Main Directorate for examination of the institutions maintained by the local funds of the Societywithout any practical sense-will deliver harm to those institutions and deprive them of any trust of the members by undermining their autonomy"3.

Further the true reasons for such actions of the Main Directorate in Saint Petersburg are listed which will not "serve well musical art ... but will only flatter the ambitions of the local Saint Petersburg Administration, which will be fully in session in the Main Directorate"4.

The attention of the Grand Princess is also drawn to the obscure urge not to grant independence to them in terms of solving of internal questions, which would make impossible the very existence of the RMS in Moscow. "... And yet not desiring to abandon our action which delivers to us such great aspirations, we decide most reverently and most diligently to demand Your Imperial Highness" not to modify the existing statute of the Society, not to perform therein any changes for Moscow, and thus, for the Society, without changing its aim, without changing its form of the Russian Musical Society, by means of adding to it one word "in Moscow", as usually, staying under Your High and beneficent patronage, to gain full independence of its actions and funds, and it will sooner and better succeed in its highest musical endeavours, which it has never stopped to strive for"s.

In other words, the Saint Petersburg Administration proposed statute projects for the Moscow RMS "which were more and more constraining and impossible to follow ... Utterly convinced that Your Majesty deeply understand the essence of musical art for Russia, we are indeed assured that You will not allow for the deed to die for the sake of which we worked to the best of our abilities, but now do not see any possibility to continue working given current conditions" 6 (Signed by the prince N.P. Troubetskoy, P.N. Lanin, N.G. Rubinstein, A.A. Torletskiy).

Nikolay Petrovich Troubetskoy was in charge of the most different activities of the Moscow RMS, including composition and editing of diverse documents (Statutes, Reports), maintaining correspondence on cooperation with state institutions and the Main Directorateof the Society in Saint Petersburg.

There was found a written inquiry to the Inspector of the Moscow Conservatoire C.C.Albrecht, bearing the date of the $28^{\text {th }}$ of February, 1868, which may have been related to the Troubetskoy's preparation of the Report of the Moscow office for the Main Directorateof the Society. In this inquiry, the prince asks Albrecht to send him: “... the programmes starting from the $7^{\text {th }}$ Assembly; the Quartet Collection of the $2^{\text {nd }}$ series, and Rubinstein's Concerto. Correct the enclosed

${ }^{3}$ Ibid.

${ }^{4}$ The Glinka National Museum Consortium of Musical Culture. F.80. S.I.3569.

${ }^{5}$ The Glinka National Museum Consortium of Musical Culture. F.80. S.I.3569.

${ }^{6}$ Ibid. information about the funds until circa the $1^{\text {st }}$ of March, about the number of students, about the number of members: actual ones, visiting ones, and performing ones; or please send these details today in the evening and no later than tomorrow in the morning at 9 o'clock.",

Our supposition that these details were necessary for the prince exactly to compose the Moscow RMS activity report is based on their correspondence to the forms of the official Reports sent to the Main Directorate. For example, it had to contain a list naming all the members of the Society (active ones and honourary ones), a description of concert activities stating the exact number of the Symphonic and Quartet Assemblies that took place, with the enclosed programmes (with all performed works and the names of the performers), a detailed financial report with information on ticket sales, hall renting, donations and many other aspects.

Apart from that, Troubetskoy worked with issues related to the concert activities of the Society in Moscow. In 1860s Troubetskoy initiated and accomplished the previously impossible massive public educational action in Moscowthe organization of the Society's public concerts. The concerts in question are those in the Moscow Manege, which underwent special reconstruction on this occasion $[4$, pp. 2021].

If we try to imagine the whole volume of the prince's daily chores, it will be our big surprise that the credit of Troubetskoy for his work for the Society and the Moscow conservatoire was noted as near as once; for example, in a sentence of the Moscow RMS chronicle written by the "official biographer" of the Moscow office N.D. Kashkin we find only one mention about him: “...the p[rince] Troubetskoy, who came to be one of the most active and influential members of the Administration afterwards for many years" [2, p. 22].

As a true music aficionado, the prince Nikolay Petrovich Troubetskoy, was a passionate admirer of the art of the first professors at the Moscow conservatoire founded beside the Moscow RMS: N.G. Rubinstein, F. Laub, B. Kosman, I.V.Grzhimal and W. Fitzenhagen; and, as he was the Head of the Moscow RMS Administration, an active participant of all working directions of the Moscow RMS, a concert organizer, and a trustee of the Conservatoire, he arranged Musical Assemblies with them partaking.

In a bevy of letters, Troubetskoy wrote about the necessity of bringing scores and stands for musicians: “... I demand you to send me ... for the today's evening a violin and a cello solos for Laub and Kosman and a trio by Mendelssohn. If you do not have them, then send to ask for them at Juergenssohn's"

It is surprising how the prince monitored even administrative work. In 1867, he adressed his directions to Albrecht:

\footnotetext{
${ }^{7}$ The Glinka National Museum Consortium of Musical Culture. F.37. S.I.3008-3014

${ }^{8}$ The Glinka National Museum Consortium of Musical Culture. F. 37. S.I.3008-3014
} 
"I most humbly demand you, dearest Karl Karlovich, to manage the soonest (underlined 3 times-O.G.) delivery of the Quartet Assembly tickets to Jurgenssohn. The sale has been published, and there are no tickets.

Besides, having learned that tickets of Visitor Members are being sold in the Conservatoire, I ask you to stop this sale immediately, since 500 tickets have been sold at Jurgenssohn's and there will be a choir with the Conservatoire students which will amount to 150 persons, but there can be only 600 persons in the Hall together with the places outside the Hall, therefore not a single ticket more should be sold for the first series of the concerts" 9 (underlined 3 times-O.G.).

The aforementioned and the other existing in the archives documents testify to what particulars the Head of the Moscow RMS office acted responsibly in current matters. The prince was sincerely captivated by the activities in disseminating musical awareness and education. He carefully planned the Society's concert and educational work which gave the opportunity to N.G. Rubinstein to concentrate on musical and artistic tasks of the Moscow office and the Conservatoire and on his own artistic work.

\section{The TROUBETSKoys' COUNTRY ESTATE NEAR MOSCOW, A MONUMENT OF THE RUSSIAN MUSICAL HISTORY}

Prince N.P. Trubetskoy was in a constant artistic cooperation with leading Moscow musicians during a concert season, and after its termination and the start of a vacational period in the Conservatory, he welcomed them in his family circle, at his estate of Akhtyrka near Moscow ${ }^{10}$.

The marvellous palace of the Trubetskoys was visible from afar. "The entrance gate was in the beginning of the main allée, on the eastern border of the Akhtyrka estate. They were two robust high brick rusticated pillars decorated above with white marble spheres... The straight and wide allée, expanding for almost three hundred metres, possessing a road from the entrance gate to the estate court of honour, was lined from each side with centennial linden trees from without and trimmed, closely planted firs from within..."

A more detailed description can be found in an investigation by the first historiographer of Akhtyrka, Dmitry Ganeshin: “...The house seems particularly beautiful from the right side of the pond and from the pier ... The entrance six-column porch at the central part of the building with the gable richly decorated with the moulding of Princes Trubetskoys' family crest,-_everything is kept in the
Classical style ... the four-column porches of the side wings are beautiful, linked to the central part with the galleries... The walls are handled with smooth rustication, they have moulding on the gables and above the window apertures with narrow frisos on the perches ... The outer walls of the house, its side wings and kitchens were painted pale yellow, but the columns and the stuccos were left white, which looked very gorgeous ... The vast and flat place between the estate house and the church ... made up the large front court, in terms of the almost geometrically perfect square ... In the centre of the court there was built a pool with a fountain, around which as well as around the established alleys roses, many gillyflowers, peonies, sweet pea and other flowers grew, and the green lawn grew in between ... At the court of honour a circular road was built, as if circumscribed by a radius going out of a centre of the fountain; the road served to access the main house, the church, and other estate buildings.

The site with the banister went beautifully together with the terrace behind it: the same style of the banister, the same fine marble vases placed on the stands decorating this corner of the house ...

The stone staircase, constructed out of natural stone on the steep right brink of Vorya, near the ferry, lead to the upper park. Up above there was a site with a bank for recreation. The "upper" park and this bank were the most popular place for rendezvous. From this site, crooked paths ran all around the park, and one of the paths, lined with little firs, lead to an attractive two-storey garden-house which carried the name "Hermitage" ... The banks were arranged in the park even in the most distant places, and cozy corners were created. In general, there were almost no artificial planting in the park. The park was created in the old cleared forest with glades and gulleys above which light bridges were hanging, built out of unpeeled young birches.

There were a dam with an icebreaker, a mill and the house of a miller. This was one of the poetic places of the Akhtyrka estate...",

One can judge nowadays about the internals of the palace only based on the memoirs of the son of Nikolay Petrovich, Prince Evgeni Trubetskoy (who became an outstanding Russian philosopher): "The showrooms - the hall, the billiard saloon, the cabinet - were magnificent and spacious; but in the meantime - there were few living-rooms ... Inside of the house ... everything was stately: the furniture made of Karelia birch, disallowing poor manners, because one could not slouch in it ... the portrait of Emperor Alexander Pavlovich in a purple outfit, with a star ... an enormous, realsize, image of some prince with hounds. This was in the dining room. In the cabinet $\ldots$ the portraits of the ancestors ... hang in the golden frames"13.

Coming to Akhtyrka and to Prince Nikolay Petrovich, his friends found a cordial welcome, comfortable resting and socializing conditions in close proximity to the calm and picturesque Russian nature. Making music “for one's own music", walks, baths, fishing were favourite pastimes of

\footnotetext{
${ }^{12}$ Ganeshin, D.S. Pp. 391-396.

13 Trubetskoy, E.N. P. 9.
} 
guests and gladdened the landlords. The Prince and the Princess were avid musicians. Sofia Alexeyevna played the piano. Nikolay Petrovich possessed a nice voice.

There are no precise details left about the repertoire of the soloists of the Akhtyrka concerts, but "the house was often filled with music performed by the most well-known, the most talented entertainers of Moscow" ${ }^{14}$. Evgeny Nikolaevich Trubetskoy wrote about them in his childhood memoirs: "The famous Cosman came to play the cello, Laub, then one of the first violinists in the world, came to play the violin; he often visited us and played the pool with me, a little child. Afterwards, a renowned student of LaubGrzhimali, Fittsenhagen the cellist, and, finally, the great N.G. Rubinstein, whom we the children loved like a family member. I remember vividly how they played a trio in Akhtyrka." 15

Nikolay Rubinstein, a brilliant pianist, the artistic director of the Moscow RMS branch, and the Conservatory director, enjoyed the special good disposition of the Prince, and Princess Sofia Alexeyevna belonged to the number of performer's admirers as well. "The head of the then allRussian musical movement, Nikolay Rubinstein, my father's friend, used to stay in Akhtyrka, and the walls fully occupied with the family portraits heard his divine playing many times" ${ }^{16}$, E.N. Trubetskoy remembered.

It is important to note that it was already in the $2^{\text {nd }}$ half of the $19^{\text {th }}$ century that musicians, the more so virtuosos, drew much attention to themselves in Russia - thanks to largescale musical and educational activity of the IRMS; musicians were considered an exceptional phenomenon and regarded in a rather "romantic" fashion. For example, Baroness N. F. von Meck in one of her letters to P.I. Tchaikovsky claimed that her ideal of a person is a musician.

It is a possible explanation of such an ease with which the most talented and enterprising artists found support in the circles of nobility and philanthropists. The same was the case of N.G. Ruinstein. According to G.A. Laroche, “...having not yet reached the age of thirty, he belonged positively to the local key figures, behaved himself with the most important seniors as an equal and was invited $<\ldots>$ to public festivities of all kinds"17.

Nikolay Grigoryevich, like his "Saint Petersburg" brother, who enjoyed the good disposition of Grand Duchess Elena Pavlovna, got as well an influential patron in MoscowPrince N.P. Trubetskoy, who had a significant status in the milieu, was well received in the top circles of power, and had the right to address directly the August patrons of the Society. A written application of Prince Trubetskoy to the Inspector of the Moscow Conservatory K.K. Albrecht, sent from Akhtyrka, is an argument in favour of such a cooperation with the High Patroness:

\footnotetext{
14 Ganeshin, D.S. P. 416.

15 Ibid. P. 416

16 Ibid. P. 407.

17 Cited after: Tchaikovsky, M.I. The life of Petr Ilyich Tchaikovsky. In 3

Vols. Moscow: Leipzig, 1900. Vol. 1, p.208.
}

"To his high excellence Karl Karlovich Albrecht

\section{Vozdvizhenka Conservatory}

My kind Sir Karl Karlovich, in order to invent the answer that we need to give to the Grand Princess ... concerning Her order on the Student Rules at the Conservatory, I demand you to send me as soon as possible a copy of these Rules which we are sending to Her Highness. Deliver the package with these papers to my house...

16th June 1870. The Akhtyrka village." 18

The researcher D.S. Ganeshin writes about the familiarity of the Trubetskoys with Petr and Anatoliy Tchaikovskies, referring to the family correspondence, where there are their names and the fact that Anatoliy performed the romances by his famous brother ${ }^{19}$.

Petr Ilyich Tchaikovsky himself mentioned his stay in Akhtyrka in the company of Rubinstein, Laub, and Cosman in a letter to Anatoliy Ilyich dated September $28,1867^{20}$. He informed him as well that he would come for several days more.

In those years, P.I. Tchaikovsky was on the verge of his fame and it is maybe his "Moscovite" life period, when he was surrounded by outstanding activists of the Moscow RMS and the professors of the "young" Conservatory, and its artistic ambiance that defined in many respects the further path of the genius.

By the time they appeared in at the Moscow Conservatory Prince Trubetskoy's foreign guests-Czech violinist Ferdinand Laub (1832-1875) and German cellist Bernhardt Cosman (1822-1890)- had already been venerable musicians.

Before coming to Moscow Laub worked in the orchestras of Vienna and Weimar, directed a Chapel in Berlin. Cosman, who made "a brilliant virtuoso career" (Kashkin) by giving concerts in Paris, London, and Leipzig was one of Laub and Nikolai Rubinstein's permanent ensemble partners.

According to the contemporary, they were "topflight artistic celebrities" ${ }^{21}$, excellent in solo and ensemble repertoire. N.D. Kashkin spoke about Laub as the greatest violin virtuoso who "surpassed almost everyone with the power of the note" ${ }^{22}$. In 1871, P.I. Tchaikovsky wrote that "... Moscow should be proud that it has this giant violinist" 23 .

Along with teaching work performers took part in the Quartet and Symphony concerts of the Moscow branch of $\mathrm{RMS}^{24}$, and also played in other cities: in St. Petersburg

18 The Glinka National Museum Consortium of Musical Culture. F. 37. S.I. 3008 .

19 Ganeshin, D.S. P.415.

20 Tchikovsky P.I. The Complete Works. Vol. 5. Literature works and correspondence. Moscow, Muzgiz. P. 123.

21 The first 25th anniversary of the Moscow Conservatory. A historical sketch by the Conservatory professor N. Kashkin. Moscow, 1891. P. 8. 22 Ibid.

23 Tchai kovsky P.I. Musical and critical articles. Moscow, 1953. P. 33 24 A list of the works is shown in the Report of the Moscow branch of the RMS for 1864-1865. These works were performed in the Quartet Assemblies, where F. Laub played the part of the first violin: the String 
Laub played in ensemble with A.G. Rubinstein and T. Leshetitsky, in Voronezh he gave a concert with pianist Y. N. Melgunov in the season of $1870-1871^{25}$.

After Laub died in 1875 (Tchaikovsky dedicated the Third Quartet in memory of the violinist) his work was continued worthily by I.V. Grzhimali (taught from 1874 to 1915). Both of them went down in history as the founders of the Moscow violin school. They taught such great virtuosos as: V.Y. Villuan (graduated in 1871), S.K. Bartsevich and I.I. Kotek (received gold medals in 1876), L.F. Arends (1877), A.A. Mykolaiv (1880) and S.I. Dochevsky (1881). Bernhard Cosman taught at the Conservatory from 1866 to 1870; after he had left Wilhelm (Vasily Fedorovich) Fittsenhagen (taught from 1870 to 1890) took his students in his class, from which later emerged the outstanding cellists, gold medalists A.A. Brandukov (graduated in 1877), P.A. Danilchenko (1880), I.F. Saradzhev (graduated in 1886 with a large silver medal).

Troubetskoy sincerely admired N.G. Rubinstein's talent, and surrounded him with his care and tutelage. And not only in matters of musical and social issues, but also in personal ones (once the Prince literally saved Rubinstein from the scandal which could adversely affect the reputation of the Moscow Conservatory ${ }^{26}$ ).

It becomes known from another letter to Albrecht that the Prince decided to provide immediate assistance in response to Rubinstein's request:

"My dear Karl Karlovich,

I've just got a telegram from Rubinstein, in which he asks to send him 1000 rubles to Wiesbaden via telegraph. $<\ldots>$ I find that it is necessary to help him and therefore I would like to send money from the Society, as a result of this, I ask you immediately upon receipt of this, i.e. tomorrow, come to me by the first car you'll manage to take, along Troitskaya road to the station Khotkovo, and then take the trolley and go to Akhtyrka, which is 3 miles away. Take a check book with you, I'll sign one ...

Prince N. Trubetskoy.

June 26, 1870." 27

Prince Trubetskoy and Rubinstein's communication was of the nature of hail-fellow - Nikolay Petrovich signed his letters with the phrase "devoted to you". Perhaps it was due to the similarity of their personalities. "... Nikolay Petrovich was sociable, cheerful, lively and very devoted. And, carried away by anything, he showed remarkable energy", - D.S. Ganeshin states $^{28}$. E.N. Troubetskoy noticed the same traits

Quartet by Schubert, the Quintet Op.44 by Schumann, the String Quartet Op.132 by Beethoven, the Quintet Op.12 Mendelssohn-Bartoldi etc.

${ }^{25}$ Russian musical society (1859-1917): The history of the branches. Creator and compiling editor O.R. Glushkova. Moscow, 2012. P. 93.

${ }^{26}$ Cf. more in: Pavlinova, V.P. Prince Nikolay Petrovich Trubetskoy - the first head of the Moscow RMS branch. In: To the $150^{\text {th }}$ anniversary of the Moscow branch of the Russian musical society (1860-2010), Compiling editor O.R. Glushkova. Moscow, 2010. Pp. 63-64.

${ }^{27}$ The Glinka National Museum Consortium of Musical Culture. F.37.

${ }^{28}$ Ganeshin, D.S. P. 404 in Rubinstein, "I remember he was always simple, clear and cheerful, endlessly cheerful and witty...." 29

\section{CONCLUSION}

The prevalence of the music in Akhtyrka continued not for so long. The destiny of "The Cherry Orchard" awaited "The Music Parnassus", which was not a surprise for the near and dear ones of Prince Nikolay Trubetskoy. His son Evgeny Nikolaevich testified: "Having fully immersed himself in music, being devoted to the interests of the large musical task, having abdicated from his personal interests and even from his family's well-being, N.P. Trubetskoy was going into bankruptcy. He organized and participated in charity actions which required funds, and he sold his lands and forests, left after the reform, so that he himself could live and raise his many children, as well as give them good education; and he was hopelessly piling debts on debts. He could only live by music or the interests related to it and communicate with the people from the musical world who were close to his personality, and he neglected personal administration of his estates - the only source of his incomes. He did not control the stewards who stole from him everywhere and led little correspondence with them - and negligently, as he did not have any energy to concentrate upon this unpleasant business at the expense of his main and favourite occupation. He brilliantly settled the matters of the musical society, but his own matters could not be worse.

On April 15, 1875, in Akhtyrka, Sofia Alexeyevna finished with a sigh the letter to her husband - in such a manner: "May the Lord help you arrange the others' business, maybe somebody will take care about us sometime". The existence of Trubetskoys' Akhtyrka, however much they loved it and however much their own children needed it, gradually proceeded towards its end"30.

After the revolution, the palace disappeared in the fire, and nowadays, only the church for the sake of the Akhtyrka icon of Mother of God bears testimony about the eternal memory of the outstanding representatives of Russian nobility - Princes Trubetskoys, who served to the glory of the Fatherland and the Russian culture.

\section{REFERENCES}

[1] D. Ganeshin. Akhtyrka. Notes local historian // Art Panorama. 1981. Num. 4.

[2] The Moscow branch of the Imperial Russian Musical Society. Outline of activities for the fiftieth anniversary of 1860-1910. Prepared on behalf of the Directorate of the Moscow Branch Distinguished Professor ND Kashkin. M. 1910. P.22.

[3] V.P.Pavlinova Prince Nikolai Troubetskoy - the first chairman of the Moscow branch of the RMS // the 150th anniversary of the Moscow Branch of the Russian Musical Society (1860-2010) / Edited and compiled by O.R. Glushkova. M., 2010.

[4] V.P. Pavlinova The role of the N.P. Troubetskoy in the history of the Moscow branch of the RMS // Russian Musical Society (1859-1917). History branches / author and editor and compiler O.R. Glushkov. M. 2012. Pp.20-21.

${ }^{29}$ Ibid. Pp. 409-410.

${ }^{30}$ Ibid. P. 414. 
[5] RSHA. F.1286. S. 27. D.267.

[6] T.Smirnova. Manor Ahtyrka and Prince Troubetskoy. Sergiev Posad, 2006.

[7] M. I. Tchaikovsky. The life of Pyotr Ilyich Tchaikovsky. Vol.I. M.; Leipzig 1900.

[8] P.I.Tchaikovsky. Music and critical articles. M. 1953. (in Russia)

[9] P.I. Tchaikovsky. Vol.V. Literary works and correspondence. M. Muzgiz. 1959.

[10] The first twenty-fifth anniversary of the Moscow Conservatory. Historical essay by Professor N. Kashkin. M. 1891.

[11] The Glinka National Museum Consortium of Musical Culture. F.37. S.I. 3008-3014.

[12] The Glinka National Museum Consortium of Musical Culture. F.80. S.I. 3569.

[13] E. Troubetskoy, Prince. From the past // Prince Troubetskoy. Russia will rise! / Comp. A.V. Troubetskoy. M., 1996.

[14] 500 years of the history of Akhtyrka. Khotkovo: Edition temple Akhtyrka Icon of the Virgin, 2004. 